\title{
From the Economic Union to the Harmonisation of Higher Education in the BRICS Countries: The Experience of RUDN University
}

Ekaterina V. Zvereva, ${ }^{\dagger}$ Nataliya M. Belenkova, ${ }^{+*}$ and Irina I. Kruse ${ }^{\dagger}$

\section{Abstract}

Since 2009 when Brazil, Russia, India, and China (South Africa since 2011) joined in the international organisation aimed at the economic development of the countries, and gain financial stability, the relations between the countries too boosted via political and cultural cooperation. The new economic, political and social environment has a high demand for competent specialists ready to work in various national agendas and interrelated frameworks of the BRICS. In this context, it is argued that professional training in the countries under discussion should be correlated as it provides grounds for quality assurance in education that contributes to the nations' sustainable development, safety, and human rights provision. This situation determines the topicality of the issue. The objective of this research is to study the higher educational environment in the BRICS countries and to compare some aspects of professional training. In doing so, the study aims to present the experience of RUDN University as one of the BRICS university network members. The hypothesis states that the harmonisation of higher education systems within regional organisations can contribute to the enhancement of both international standards and individual learning paths, thus fostering youth rights for education in line with quality standards and individual preferences. To accomplish the objectives of the study, it uses the following methods - the review of the current research, formal document and online resources on higher education in the BRICS countries; the survey of the undergraduates, graduates, and postgraduates on their motivation to academic mobility, and collaboration in the frameworks of BRICS higher education. The data has been analysed employing the methods of statistical processing, qualitative and quantitative methods. The findings of the current research include the outcomes and findings on the harmonisation of higher education in the frameworks of BRICS higher education. The study will contribute to further development of BRICS countries education and the harmonisation of higher education.

Keywords: BRICS; Higher Education; Harmonisation; Collaboration

\footnotetext{
${ }^{\dagger}$ Associate Professors, Peoples' Friendship University of Russia - RUDN University, Moscow, Russia

${ }^{*}$ Corresponding Author, Email: belenkovanm@mail.ru

(C)2020 Zvereva et al. This is an Open Access article distributed under the terms of the Creative Commons Attribution License (http://creativecommons.org/licenses/by/2.0), which permits unrestricted use, distribution, and reproduction in any medium, provided the original work is properly cited.
} 


\section{Introduction}

The educational level is one of the essential elements of the development of any country, the increase of human potential, a tool to reduce social inequality and foster human rights in general and that of the youths. Education and evolution of human potential affect the formation and transformation of society and are considered as an investment to the national economy of any country in world practice. The feedback of investments on education, including direct and indirect costs of learning, professional training, and continuous professional development is several times higher than the input investments. It provides not only the increase in the income of individuals but also of society. The incomes of people with higher education exceed the average level of other people's income (Human Development Indices and Indicators, 2018).

The competitiveness of human resources on the scale of the international labour market and the position of each country in the international arena depend directly on the success of the implemented policy in the domain of human resources development, and their access to education. High level of investments in education and science has ensured sustainable economic growth in the country (Investing in People to Build Human Capital, 2018; LEARNING to realise education's promise, 2018).

The BRICS countries are the countries with the fastest-growing economies; they are beginning to play an increasingly important role on the world stage; they show constant growth, strengthen their influence on the world stage. This means that they are beginning to compete in higher education with the countries of Europe and the USA.

Accordingly, the economic growth entails the strengthening of political influence and the educational opportunities of the BRICS countries. Moreover, educational services can be attributed to the tools of "soft power", and, thus, are an important component of the strategy of each country. So, each country seeks to develop its national educational potential and the educational potent in the frames of the BRICS organisation. Against this backdrop, this study discusses the higher education experiences of RUDN University. It begins with a brief review of the literature. Following this, it discusses the methods employed in this study. The results of the study are critically discussed in the sections following the methodology.

\section{Literature Review}

The existing research on the issues of education in general and higher education in the BRICS countries focuses on the achievements of some countries in the economic and social integration. For instance, many scholars have compared the international status of higher education in China and India (Fielden, 2010; Lavakare, 2018). Economic and political globalisation resulted in globalisation in higher education; BRICS countries have been integrated into the global educational environment and achieved great success (Lunev, 2014). In recent years the methodology to select priorities for the cooperation in science and technology among the BRICS countries has been developed (Sokolov et al., 2017). The correlation of education parameters and expenditures within BRICS countries' higher education has been investigated (Gupta, 2017).

The World Bank sponsors education development, including higher education in developing countries. The main priorities of the World Bank in training qualified and active population, including high-level scientists, specialists, engineers, teachers of primary, secondary and higher schools, as well as forthcoming members of the government, public service and business are:

- to help them in obtaining new knowledge;

- to develop their ability to access existing global knowledge repositories and adapt this knowledge for the local use (Hopper et al., 2008; Salmi et al., 2010). 
The development of higher education boosts the economic growth in BRICS countries (Chang et al., 2018).

The correlation of the curricula, methods, and principals of higher education, that is the harmonisation of education in the BRICS countries is viewed, but the focus is made on statistical data (Yampolskaya et al., 2019) or the comparative analysis of the BRICS educational systems (Arruda et al., 2015).

The cultural and intellectual diversity of the BRICS countries is concentrated in some research (Zaidan, 2019). National higher education faces many challenges (Agarwal, 2009), in some cases, they are typical of all countries of the region, e.g. Brazil being a member of the BRICS also faces the problems of higher education in other Latin America countries (Brunner \& Pedraja-Rejas, 2017).

The similarities and differences are indicated between some BRICS countries. The similarities are observed by the Global Competitiveness Index (Bil et al., 2018).

It is essential to consider the language issues within the internationalisation of higher education that goes beyond language specialist training and uses language as a tool for human and professional development in various areas of knowledge. This approach requires a meticulous analysis of students' expectations and needs (Atabekova, 2016). As for Russian Universities, their activities confirm that comprehensive language policy should be drafted and implemented as a response to the needs for internationalisation, on the one hand (Atabekova et al., 2016). This study discusses the harmonisation of Higher Education using the experiences of RUDN University.

\section{Methodology}

The threefold objective of the research included the examination of the educational environment in BRICS countries higher education institutions; the observation of some aspects of the professional training; the presentation of the experience of one of the BRICS universities. These objectives determined the methods of the research.
The principal method of the current research is the examination of research papers, curricula, the practical experience of teaching and training in higher education institutions of the BRICS countries. The formal documents are also studied. All materials are analysed, focusing on the differences and similarities of the higher education environments in Brazil, Russia, India, China, and South Africa.

The information gained from various sources such as online resources, papers of modern researchers, declarations and other documents of BRICS Summits and the UN were generalised.

One of the research steps was to hold a brief survey among the RUDN students who studied at bachelor, master and postgraduate levels of professional education. The survey was held from March to June 2019 and comprised of 4 questions, one of which was open-ended, and two others assumed the choice of the given options:

- Would you like to continue your education and professional training in one of the BRICS Universities? (Yes/No/Have no information)

- If your answer is positive, what country would you like to study in (Brazil, India, China or South Africa)?

- Give reasons for your positive/negative reply. Comment on your choice.

- What is your opinion about academic mobility? (consider the practice from various angles, that is language of instruction, a country in a particular region, etc.)

The above open-ended questionnaire laid grounds to consider the educational environment through the angles of education quality, access to education, and consequently youth rights concerning education within the different learning environments, including stages, national specifics, and individual needs.

Fifty undergraduates, 40 graduates and 25 postgraduates of Law Institute of RUDN University participated in the survey. To summarise the data of the survey, the statistical method of discrete quantitative analysis was 
used. The results of this study are discussed critically in the following sections.

\section{Results and Discussion}

Having studied the diversity of resources, the following findings can be observed:

\section{Educational Challenges in the BRICS Countries}

In recent years, the growth of higher education in countries such as Brazil, India, and China can be noted. A mature and stable educational system characterises the Russian Federation. South Africa is just forming and starting to develop its sphere of higher education as it is situated quite far and has some cultural contradictions.

In connection with the growing need for the development of higher education, each of the BRICS countries is perfecting its own, bilateral and multilateral national strategy of cooperation. The BRICS countries must satisfy the country's economic and social needs at the same or higher level, developing universities to the level of world recognition (Schwarzman et al., 2015).

Brazil, India, and China are actively developing a research component to ensure the formation of world-class universities. This goal is actively achieved by universities in China, which demonstrate their growth in international educational ratings. The Russian universities reform their educational system from universities that provide educational services to universities that carry out the equivalent research activities.

The BRICS countries have not yet become leaders in higher education; they are experiencing rapid growth, introducing programs to increase the competitiveness of their universities. Nevertheless, Russia is a leader in higher education in the post-Soviet space, and in other countries such as Mongolia, and Afghanistan. In East Asia, China is rated in the top three after Japan and South Korea.

In the BRICS countries, higher education is provided in the national language, except for South Africa, where English is the official language; but India too delivers higher education in English, Hindi and other official languages of the states. However, other countries are introducing separate higher education programs in English, thereby attracting international students.

Another problem of the BRICS countries is academic migration. However, Brazil practically does not feel the impact of academic migration, as a significant number of students and teachers return to their motherland. China provides better conditions for those who have not left the country. India has several programs designed to ensure academic return. In South Africa, the outflow is significant, which is explained by the post-apartheid state policy. In Russia, the consequences of a significant outflow of "brains" are being eliminated by investing in research universities and adopting special programs, for example, the "TOP 5-100" project.

BRICS countries lack common standards of higher education. Such difficulties are due to the lack of funding, which makes some goals challenging to achieve to the level of world recognition (Roberto, 2019).

The research sector of the BRICS countries is developing in various ways. Russia and China split research and educational activities; the countries transfer the functions of scientific research to educational organizations. China adopted Project 211 and Program 985, which ensured the formation of the necessary infrastructure for universities. Brazil, India and South Africa pursue a policy of the integration of educational and scientific activities, created large scientific and educational centers. Brazil contributes much to the harmonisation of the national curricula and professional training of the specialists to be (Fiallos et al., 2014). All these actions increase the positions of the BRICS universities in the world ratings.

The top ten in the world ranking of universities are taken by first and foremost, Chinese universities. This fact testifies to an effective policy to increase the competitiveness of China's higher education system in the international arena. There is also one university from Russia and two universities from India, which may also indicate effective measures taken by the 
governments of these countries to increase the position of national universities in the international rankings (QS BRICS Top Universities, 2019). It is worth noting that the positions of universities in the ranking are affected by indicators - reputation/image in the academic environment, reputation/image of employers; the ratio of the number of faculties to the number of students; the citations of the university academic staff; the share of foreign teachers; and the share of foreign students studying at the university.

Such an indicator as the reputation in the academic environment is shaped as a result of a survey of prominent world representatives of the scientific and educational environment, as well as the employers. Following this indicator, Chinese universities have the best reputation among the BRICS countries. The Russian universities take the second place; Brazil and India were approximately in equal positions in the third place. The lowest positions are held by the universities from South Africa (QS BRICS Top Universities, 2019).

In July 2018 BRICS Summit was held in South Africa. The Declaration of this meeting emphasised the importance of strengthening the cooperation and exchange of experience of the BRICS countries in higher education; the achievement of a complete and high-quality education by 2030 . To reach this goal, it was decided to form a working group for the general recognition of education diplomas and diplomas of scientific qualifications, as well as the harmonisation of educational standards of the BRICS countries (BRICS in Africa: Collaboration for Inclusive Growth and Shared Prosperity in the 4th Industrial Revolution, 2018).

\section{Guidelines of Higher Education Harmonisation}

Harmonisation of educational paradigms can and should become the basis of a strategy for the development of education in general, and higher education in particular. At the same time, it plays the role of a stabilising factor in education.

The basic principles of harmonisation of educational paradigms can be specified as follows:
- the principle of pedagogical pluralism: the recognition of equal, partnership coexistence of all educational paradigms and pedagogical practices;

- the principle implying the awareness of the firm and weak points of each of the educational approaches;

- the principle that assumes that the combination of approaches will vary at each stage of the learner's development, it should also be carefully thought out, justified, and technologically provided.

- the principle of the field overlap, which allows, on the one hand, to see the areas of application common to different paradigms, and on the other hand, to determine the importance of each of them in solving a specific pedagogical problem.

The above principles laid grounds for both quality assurance and respect to learners' rights for the individual learning paths in education.

The interpretation of the above principles in their practical realisation proved that though the national education systems in BRICS countries are different, the similar characteristics should be identified. The harmonisation in higher education can be realised in the following directions: the accumulation of new knowledge; the development of the abilities to adapt new information to the national environment; wellqualified training of specialists of all levels and various professions.

Net Universities of the BRICS countries provide an excellent opportunity for learning mobility. The academic output of such learning is the opportunity to get dual diplomas, that is the diplomas of both higher education institutions. The primary method of functioning of this university is the organization of double diploma programs, which implies high academic mobility. For example, two-year master's programs are envisaged, in which the first year of study takes place in the country of residence, and the second in another BRICS country. At the same time, the working languages of the university are Russian, Chinese and English. 
The above features contribute to fostering international higher educational standards of quality assurance.

Moreover, the mentioned options lay grounds for individual trajectories in higher education that are arranged in line with learners' needs and preferences. This, in turn, provides conditions for youth rights implementation in the field of BRICS countries' higher education framework. The following section narrates the harmonisation experience of higher education of RUDN University.

\section{RUDN University as a Member of BRICS Net University}

One of the examples of the harmonisation of higher education is the BRICS Net University. RUDN University (Peoples' Friendship University of Russia) held the research "Development of methodological principles and tools for the analysis of educational statistical indicators of the BRICS countries for information and analytical support for decision-making based on monitoring systems of the national education".

Having considered various indicators, RUDN specialists analysed the educational systems of the BRICS countries (Brazil, Russia, India, China, and South Africa) and focused on various facts. For example, the idea of overcoming literacy and eliminating racial and social inequalities is still relevant in Brazil, India and South Africa. The "computerisation" of education and the reform of the university system in addition to the improvement of its quality is a priority for Russia and China. The "positive dynamics" of the international competitiveness of the BRICS universities in various "ratings" were also reported.

The goal of the RUDN initiative is to promote the "convergence and harmonisation of education systems" among the BRICS countries and to promote the mobility of students and the joint projects in science and education.

RUDN University made a significant contribution to the harmonisation of BRICS countries' higher education. The relevant achievements and initiatives of the University academic community are: the implementation of digitalisation at
RUDN University as a cross-cutting technology that increased the level of education development (Atabekova, 2017); the participation of "E-Education" projects; the multilateral development of students' general and professional competencies; the development and implementation of consultation mechanisms, methodological and technical support, including multimedia electronic tools, interactive electronic materials and international webinars in the domain of training; the creation of infrastructure and technical capabilities (that is, the inclusive environment) for involving persons with special needs (physically challenged students) in the educational system; making an electronic portfolio to expand the students' learning mobility.

Nowadays 31,500 students, including 9000 international students from 157 countries worldwide learn at RUDN University. The University runs 472 educational programs including 150 joint educational programs. It comprises 7 faculties, 10 Institutes, an Academy of Engineering and 156 research laboratories in the structure of the University. All these institutions and departments ensure the widest opportunities for high-quality education of the students.

18 undergraduate and graduate courses of the RUDN University have international accreditation. Besides educational activity RUDN university is known for its expanded research activity supervised by Russian and international scholars. More than three thousand students continue their professional and academic development in the Ph.D., postdoctoral, residency or internship courses. The RUDN University interdisciplinary research and scientific schools have academic recognition both in Russia and overseas countries (QS Top Universities, 2019).

RUDN University is one of the most well-known multinational and multicultural higher educational institutions of Russia. Many students from BRICS countries study at the University. The highest number of international students are from China (about 600). More than 
150 students came from South Africa, about 60 students are from India, and about 40 students are from Brazil.

At the same time, Russian students continue their education in the universities of the BRICS countries. In this connection, the survey focused on the Russian students' intention to study at one of the universities of BRICS countries was held.

\section{Students' Views Concerning Academic Mobility Within BRICS Network}

The number of students who want to study in one of the BRICS countries varies in accordance with the level of education. $35 \%$ of those who study at a bachelor level look forward to international/transnational education and professional training. The number of graduates and postgraduates with the same goal reaches $42 \%$ and $47 \%$ respectively.

On the other hand, $25 \%$ of undergraduates, $46 \%$ of graduates and $48 \%$ of postgraduates are quite satisfied with the education of the Russian

\section{Table 1: The Rating of BRICS Universities by the Russian Students' Opinion}

\begin{tabular}{l|l|l|l}
\hline & Bachelors level & Masters level & PhD level \\
\hline Brazil & $23 \%$ & $21 \%$ & $25 \%$ \\
\hline China & $32 \%$ & $33 \%$ & $54 \%$ \\
\hline India & $23 \%$ & $22 \%$ & $12 \%$ \\
\hline South America & $27 \%$ & $28 \%$ & $15 \%$ \\
\hline Source: Authors & &
\end{tabular}

university and do not want to go abroad. Among other reasons for their resistance vis-à-vis unwillingness, the respondents of the survey mentioned the intention to live in a comfortable environment and the ingrained fear of travelling out of their comfort zones. The respondents seeking Masters and PhD degrees explained their reluctance to study abroad for the following reasons:

- they already started their families,

- have children

- and accomplished promotion at work.

The number of students who do not know anything about BRICS Net University decreases from $40 \%$ (undergraduates) to $12 \%$ (graduates) and $5 \%$ (postgraduates).

The opinions of the respondents on the country where they wish to get further education are almost similar on the first and second academic levels but change significantly on the PhD level. However, the reasons for their choice are identical (Table 1).
The most significant number of respondents have great intentions to study in the universities of China, their interest is explained by the high quality of professional education, the development of ICT and their use in research and training.

The respondents who want to study in Brazil are attracted by a comprehensive practice of academic mobility of universities and not very high tuition fees for foreign students. Higher education of South Africa is characterised by the cooperation of higher educational institutions and large industrial enterprises and by high investment in higher education.

The respondents do not mention Universities of India in the first lines as they mentioned a lack of information about concrete universities that would be ready to accept them for studies. Nevertheless, those who want to continue their education in Indian universities suppose that the main advantage of the national higher education is the high level of employability of the future specialist. Moreover, the reasons to continue education in India are related to the widespread opinion that the world-known specialists and researchers with education backgrounds from the world's best institutions work as instructors at Indian universities.

All the respondents mentioned the importance of the academic opportunity mobility within both concrete universities and more extensive 
international agreements on network education practice.

Below, we provide the types of responses (reasons) that the participants of our survey provided. According to the participants' responses for the open-ended questionnaire, the highest results are associated with specialisation choice (92\%), the language of instruction (98\%), learning trajectories (92\%), opportunities to choose a particular region and country of the world about future professional activity specifics (91\%).

\section{Conclusion}

The creation of the BRICS education area marked significant changes in the higher education system of the countries and promoted the integration of various aspects of higher education. The universities play a crucial role in the consolidation and development of intellectual, cultural and social areas of the BRICS countries. The idea of the common educational space and the harmonisation of higher education requires guidelines that include the agreements between political and academic actors regarding the educational model, the analysis of best practices, the development of research, and common standards. Above all, the definition of common spaces should achieve the appropriate recognition in global educational and academic society.

The above activities, when aggregated into a common action plan, contribute to the overall development of the nations within the global context.

Moreover, the present study reveals that harmonisation of higher education within the regional international organisation, contributes to implementing human expectations on individual learning paths, provides pathways to fostering youth rights for education in line with quality standards and personal preferences.

The collaboration of programs, regular meetings and seminars, which result in a strategic route with the identified goals and actions, should be held to achieve higher education harmonisation. Complete awareness of the development of mutual trust between higher education institutions; the coordination of the framework of the educational structure; the search for terms of the framework for qualifications; the foundations for recognising periods of study, the definition of elementary principles related to the significance and activities of these institutions; the coordination in the framework of the educational structure without abandoning the specific characteristics of each particular system are of primary importance.

Provided that the mentioned features are under implementation, they lay grounds for learners' trajectories in higher education that are arranged in line with their needs, thus ensuring conditions for youth rights provision and implementation in the field on BRICS countries' higher education framework.

\section{References}

Agarwal, P. (2009). Indian higher education:

Envisioning the future. New Delhi: Sage

Publications India.

Arruda, P.L., Slingsby, A.K., Ustyuzhantseva, O., \& Nafey, A. (2015). Educational systems of the $B R I C S$ countries: preliminary findings of a comparative, present and future time, adequacy analysis. Retrieved on 4 September 2019 from, http://www.nkibrics.ru/system/asset_docs/dat a/5568/7b19/6272/693b/d15e/0000/original/P edro_Arruda_Session9.pdf?1432910617

Atabekova, A. (2017). ICT-based visualisation for language and culture mediation skills training: addressing societal needs. ProcediaSocial and Behavioral Sciences, 214, 511-519.

Atabekova, A. (2016). Multilingualism in higher education: Pros and cons according to university students. INTED2016 Proceedings, 4947-4954.

Atabekova, A.A., Gorbatenko, R.G., \& Shoustikova, T.V. (2016). University academic excellence and language policy: A case of Russia. International Journal of Environmental and Science Education, 11(16), 9390-9397.

Bil, E., Güdük, T., \& Keskin, G. (2018). The study of evaluation BRICS-t countries based on the global competitiveness index. Journal of Life Economics, 5(4), 127-140. 
BRICS in Africa: Collaboration for Inclusive Growth and Shared Prosperity in the 4th Industrial Revolution (2018). 10th BRICS Summit Johannesburg Declaration. Johannesburg, South Africa, July 26, 2018. Retrieved on 4 September 2019 from,

http://www.brics.utoronto.ca/docs/180726johannesburg.html

Brunner, J.J., \& Pedraja-Rejas, L. (2017). Los desafíos de la gobernanza de la educación superior en Iberoamérica. Ingeniare, 25(1), 2-7.

Chang, V., Chen, Y., \& Xiong, Ch. (2018).

Dynamic interaction between higher education and economic progress: a comparative analysis of BRICS countries. Information Discovery and Delivery, 46(4), 225-238.

Fielden, J. (2010). Higher Education in the New Economies. In E. Baker, P. Peterson, B. McGaw (Eds.), International Encyclopedia of Education (pp. 520-526). Amsterdam: Elsevier Ltd.

Fiallos, Z.M., Green, I., \& Rodriguez, N. (2014). Posibilidades de la Armonización de la Educación Superior en Centroamérica: El Caso de la Carrera de Educación Comercial de la UPNFM. Paradigma: Revista de investigación educative, 20(31), 19-32.

Gupta, D.B. (2017). A comparative study of basic education parameters for BRICS and their relationship with expenditure on education. Journal of humanities and social science, 22(9), 1-18.

Hopper, R., Salmi, J., \& Bassett, R. (2008). Transformar la educación superior en los países en vías de desarrollo: el papel del Banco Mundial. In La educación superior en el mundo: Educación superior, Nuevos retos y roles emergentes para el desarrollo humano y social. Madrid: Mundiprensa.

Human Development Indices and Indicators (2018). Retrieved on 4 September 2019 from, http://hdr.undp.org/sites/default/files/2018_su mmary_human_development_statistical_updat e_en.pdf

Investing in People to Build Human Capital (2018). Retrieved on 4 September 2019 from, https://www.worldbank.org/en/news/immersiv e-story/2018/08/03/investing-in-people-tobuild-human-capital

Lavakare, P.J. (2018). India and China: Two major higher education hubs in Asia.

International Higher Education, 94, 12-13.

LEARNING to realize education's promise (2018). Retrieved on 9 September 2019 from, https://www.worldbank.org/en/publication/wd r2018

Lunev S. (2014). BRICS countries in globalization processes. Comparative Politics, 3 (17), 81-108.

QS BRICS Top Universities, (2019). Retrieved on 4 September 2019 from,

https://www.topuniversities.com/universityrankings/brics-rankings/2019

Roberto, A. (2019). Opportunities and challenges for BRICS Countries: The International environment and policy outlook for BRICS countries. In L. Wang, J. Zhao (Eds.), The coordination of BRICS development strategies towards shared prosperity. Beijing: Publisher Social Sciences Academic Press.

QS Top Universities (2019). Retrieved on 24 September 2019 from, https://www.topuniversities.com/universities/r udn-university

Salmi, J., Malee, R. \& Bassett (2010). Transforming higher education in developing countries: The role of the World Bank. In International Encyclopedia of Education (pp. 590-596). Amsterdam: Elsevier Ltd.

Schwarzman, S., Pinheiro, R., Pillay, P. (2015). Higher Education in the BRICS Countries. New York: Springer.

Sokolov, A., Shashnov, S., Kotsemir, M., \& Grebenyuk A. (2017). Identification of priorities for S\&T cooperation of BRICS countries. International Organisations Research Journal, 12 (4), 32-67.

Yampolskaya, D., Korneeva, A., Cai, H., \& Campolina B. (2019). Harmonization problems of the education systems indicators in the BRICS countries. BRICS law journal, 6(1), 5-40. 
Zaidan, S. (2019). The most prominent political ideas of the BRICS group. Tikrit Journal for Political Science, 14, 191-214.

\section{Acknowledgments}

The publication has been prepared with the support of the RUDN University program under 5-100 Russian Academic Excellence Project, research project number 090512 -1- 274. 